\title{
Problematika Pembelajaran Matematika di SD Muhammadiyah Kampa Full Day School
}

\author{
Annisa $^{1}$, Zubaidah Amir $\mathbf{M Z}^{2}$, Rian Vebrianto ${ }^{2}$ \\ 1,2,3 Program Studi Magister Pendidikan Guru Madrasah Ibtidaiyah, Universitas Islam Negeri Sultan Syarif \\ Kasim Riau \\ e-mail:21910125568@,students-uin.suska.ac.id
}

\begin{abstract}
This study aims to identify and obtain information about problems in mathematics learning in elementary schools. This research is a case study research. The time span of this research was carried out in October 2020. In this study there were 2 sources, namely teachers of SD Muhammadiyah Kampa Full Day School. Data collection in this study is through interviews. The results showed that there were several problems experienced by the teacher in learning mathematics which included: the aspect of the teacher having difficulty developing the material in the book because there was too much material to be taught and the teacher only used a conventional learning approach. For the aspects of students, namely the lack of student interest in learning mathematics, understanding of concepts that are not mature, lack of enthusiasm for learning and students are not motivated when studying mathematics, many students consider mathematics to be a difficult and boring subject, students often solve problems by using general formulas or rules and the inability of students to learn independently. And the last is the environmental aspect of the classroom atmosphere which is less conducive.
\end{abstract}

Keywords: Learning, Mathematics, Learning Problems.

\section{PENDAHULUAN}

Pembelajaran matematika di sekolah dasar merupakan mata pelajaran yang wajib dipelajari siswa. Matematika mempunyai manfaat yang bisa siswa dirasakan sendiri, khususnya di kehidupan siswa. Dari tahun ke tahun, matematika berkembang semakin meningkat sesuai dengan tuntutan zaman yang mendorong manusia untuk lebih kreatif dalam mengembangkan atau menerapkan matematika sebagai ilmu dasar. Mata pelajaran matematika sebagai ilmu dasar (basic of science) berkembang pesat, baik materi maupun kegunaanya di dunia ilmu pengetahuan dan teknologi. Dalam mengimbangi kemajuan 
tersebut diharapkan siswa mampu merespon dengan berbagai sikap kritis, kreatif, dan menyadari bahwa matematika itu penting bagi kehidupannya.

Matematika memang suatu ilmu yang abstrak. Mungkin pula sulit dicerna. Ini wajar. Namun sebagai guru haruslah senantiasa berupaya menunjukkan relevansi matematika dalam kehidupan nyata. Realita yang didapatkan lapangan bahwapeserta didk banyak yang mempunyai persepsi tentang tidak relevannya atau tak bermanfaatnya matematika dalam kehidupan sehari-hari, motivasi belajar matematika peserta didik turun, atau malahan menjadi hilang akibatnya, banyak dari anak-anak kita itu menghafal matematika dan guru terkadang hanya mengajar dengan startegi konvesional.

Tetapi kenyataan yang terjadi sekarang ini, masih banyak orang yang memandang matematika sebagai suatu mata pelajaran yang sangat membosankan dan menyeramkan. Sebagaimana yang diungkapkan oleh Sudarman bahwa sebagian siswa masih mempunyai kesan negatif terhadap matematika, misalnya: matematika sebagai pembelajaran yang menakutkan, matematika sulit dan membosankan, matematika tidak menyenangkan matematika merupakan ilmu yang kering, melulu teoritis dan hanya berisi rumus-rumus, seolah-olah berada "di luar" mengawang jauh dan tidak bersinggungan dengan realitas siswa (Zubaidah Amir, 2013).

Kenyataan-kenyataan tersebut diperkuat dengan adanya hasil penelitian Eva yang mengatakan secara umum siswa menganggap bahwa matematika ilmu yang sulit dan menakutkan. Padahal jika siswa memiliki kesan negative terhadap pelajaran matematika, tentu hal ini akan berpengaruh dalam proses dan hasil belajarnya. (Zubaidah Amir, 2013).

Dalam proses pembelajaran di sekolah, guru memegang peranan yang amat penting dan strategis. Kelancaran proses seluruh kegiatan pendidikan terutama di sekolah, sepenuhnya berada dalam tanggung jawab para guru. Ia adalah seorang pemimpin yang harus mengatur, mengawasi dan mengelola seluruh kegiatan proses pembelajaran di sekolah yang menjadi lingkup tanggung jawabnya. Dengan demikian permasalah yang dibahas dalam penelitian ini adalah problematika yang di hadapi guru matematika dalam proses pembelajaran.

\section{METODOLOGI}

Pendekatan penelitian ini adalah penelitian studi kasus untuk menghasilkan gambaran yang jelas dan terperinci mengenai problematika pembelajaran matematika di SD Muhammadiyah Kampa Full Day Shcool. Data diperoleh melalui wawancara dengan 2 
guru dengan tujuan untuk menemukan apa saja yang menjadi prolematika guru selama proses pembelajaran matematika dalam kelas, kemudian guru yang diwawanara diminta untuk memberikan solusi dan ide-ide untuk mengatasi masalah yang berkaitan dengan problematika guru dalam proses pembelajaran matematika. Langkah-langkah yang dilakukan dalam menganalisis data yang didapat yaitu dengan menyusun data secara sistematis, menjabarkan, memilih dan memilah data yang penting serta membuat kesimpulan.

\section{TEMUAN DAN DISKUSI}

Secara umum penelitian bertujuan untuk mengidentifikasi problematika guru dalam proses pembelajaran matematika serta bagaimana cara guru mengatasi kesulitan tersebut. Berdasarkan hasil wawancara dengan guru terdapat beberapa probemtika yang dialami oleh guru ketika proses pembelajaran matematika:

Berdasarkan problematika yang di hadapi pada aspek guru dijelaskan bahwa:

Guru kesulitan mengembangkan materi yang ada dalam buku karena teralu banyak materi yang akan diajarkan

"Saya sebagai guru juga terkadang sulit untuk mengembangkan materi yang akan diajarkan karena sumber yang didapatkan terlalu sedikit"

Guru kesulitan mengembangkan materi yang berada dalam buku karena materi matematika yang berada dalam buku sangat terbatas dan hanya sepintas menyebabkan guru harus pintar-pintar mencari materi tambahan untuk mengajarkan konsep-konsep kepada siswa. Peran guru harus berubah dari seorang validator (menyalah/membenarkan) menjadi pembimbing yang menghargai setiap kontribusi (pekerjaan dan jawaban) siswa (Nur Atika \& Zubaidah Amir MZ, 2016).

\section{Guru hanya menggunakan pendekatan pembelajaran konvensional}

"Saya kalau mengajar menggunakan pendekatan ceramah dan tanya jawab kalau mau membuat media itu membutuhkan waktu sedangkan saya bukan hanya mengajar matematika saja tetapi mupel yang lain juga"

Guru juga terkadang hanya menggunkan pendekatan bahkan strategi yang monoton karena mengingat waktu yang terbatas sehingga guru lebih banyak menggunakan pembelajaran konvensional. Padahala Salah satu peran matematika adalah untuk meningkatkan berbagai kemampuan maupun kecerdasan seseorang dalam berbagai aspek kehidupan. Jika kita mempelajari matematika maka kita akan terbiasa dalam menyelesaikan El-Ibtidaiy: Journal of Primary Education, Vol. 4, No. 1, April 2021, Hal 95-105 
berbagai permasalah kecil hingga besar, berpikir positif, kreatif, kritis, logis dan sistematis ( Pasaribu Endi Zunaedy, dkk, 2020).

Berdasarkan problematika yang di hadapi pada aspek siswa dijelaskan bahwa:

\section{Kurangnya minat belajar siswa pada pelajaran matematika}

“Anak-anak itu malas kalau sudah menyangkut pelajaran matematika sulit katanya ditambah kita sebagai guru cuma dapat mengajar matematika sekilas, kalau tidak dikasi motivasi disela-sela belajarnya yaah mereka tidak mau memperhatikan pembelajaran"

Salah satu faktor penyebab kesulitan belajar siswa adalah kurang berminat terhadap pembelajaran matematika, sehingga siswa tidak memperhatikan materi dan akhirnya tidak memahami konsep. Dalam kasus lain, siswa hanya menghapal rumus atau konsep, bukan memahaminya. Akibatnya, siswa tidak dapat menggunakan konsep tersebut dalam situasi yang berbeda karena pada dasarnya minat sangat mempengaruhi terhadap proses dan hasil belajar. Kualitas minat belajar akan seiring dengan kualitas hasil belajar. Semakin tinggi minat belajar siswa, maka akan semakin bagus pula hasil belajarnya (Zubaidah Amir, 2015).

\section{Pemahaman konsep yang kurang matang}

"Anak-anak juga sekarang itu lagi malasmalanya kalau menghafal rumus, sekarang apa-apa kesulitannyakan sukanya nyari diinternet jadi mereka malas hafalin rumus yang diberikan dikelas. Entah ini pengaruh globalisasi atau apa jadi tiap dikasi rumus ndak pernah mau mahamin atau ngafalin jadi saya harus ngulang-ngulang lagi pelajaran yang tidak diingat sedangkan materi yang akan diajarkan masih banyak yang belum"

Guru mengeluhkan bahwa siswa malas belajar dan menghafal rumus tanpa memahami konsep (Fika Nopia, 2020). Pembelajaran matematika di sekolah sebagian besar masih memfokuskan pada ketrampilan dasar yaitu menghafal dan menerapkan rumus (Anwar Eko Syaiful, 2020).

Salah satu kesulitan yang dihadapi siswa ialah bentuk soal yang menyajikan permasalahan terkait dengan kehidupan sehari-hari dalam bentuk cerita dalam operasi hitung dapat terjadi karena siswa melakukan kesalahan dalam mengoperasikan angka secara tidak benar (Muntaha Agus 2020). Siswa juga kesulitan dalam keterampilan menghitung karena tidak teliti ketika menghitung sesuai dengan pendapat (Runtukkahu, 2014) bahwa siswa yang mengalami kesulitan belajar matematika sering melakukan kekeliruan dalam berhitung (Utari Dian Rizky, dkk 2019).

Semangat belajar yang kurang dan Siswa tidak termotivasi saat belajar matematika 
"Siswa kurang bersemangat saat belajar matematika belum lagi terkadang guru yang mengajar killer"

Guru hendaknya memberikan semangat kepada peserta didik bahwa sebagai pelajar hendaknya mencintai ilmu termasuk pembelajaran matematika, memang tidak dapat pungkiri bahwa mata pelajaran matematika menjadi momok bagi peserta didik, sehingga motivasi belajar menjadi faktor untuk menentukan keefektifan dalam pembelajaran (Diana Putri Utami \& Melly Andriani, 2019).

"Peserta didik saat pembelajaran matematika terkadang tidak mendengarkan penjelasan guru karena siswa beranggapan bahwa pembelajaran matematika hanya selalu tentang rumus dan angka-angka tanpa ada aplikasi dalam kehidupan sehari-hari"

Pernyataan siswa bahwa pelajaran matematika merupakan pelajaran yang membosankan, guru matematika merupakan guru yang killer. Siswa malas masuk pelajaran matematika sehingga menjadikan proses pembelajaran menjadi sangat membosankan sehingga siswa tidak mempunyai yang tinggi untuk belajar (Kamarullah, 2017). Dikalangan siswa banyak yang memandang matematika adalah mata pelajaran yang sulit dan membosankan. "Siswa beranggpan bahwa matematika pelajaran sulit belum lagi rumusrumus yang harus di hapal luar kepala dan tuntunan materi yang makin sulit"

Matematika merupakan bidang studi yang dianggap paling sulit oleh para siswa, baik yang tidak berkesulitan belajar dan terlebih bagi siswa yang berkesulitan belajar (Elfina Hetty, 2020) dan cara berfikir seseorang dipengaruhi oleh pendidikan yang di dapat oleh seseorang ( Berlian Arista Putri dan Fuaddilah Ali Sofyan, 2020). Hal ini sesuai dengan yang dikemukakan Russefendi bahwa "terdapat banyak anak-anak setelah belajar matematika bagian yang sederhana, banyak yang tidak dipahaminya, dan banyak konsep yang dipahami secara keliru. Matematika dianggap sebagai ilmu yang sukar dan banyak memperdayakan” (Novitasari Dian, 2016).

Pembelajaran matematika yang masih rendah disebabkan karena berbagai permasalahan. Salah satu permasalahan dalam pembelajaran matematika yaitu anggapan dari sebagian besar siswa bahwa matematika adalah pelajaran yang sulit dan membosankan, sehingga banyak siswa yang kurang menyukai pelajaran matematika bahkan menjadikan matematika sebagai salah satu pelajaran yang harus dihindari. Padahal siswa yang kurang menyukai pelajaran matematika dapat mengalami kesulitan dalam memahami materi yang disampaikan dan berdampak pada rendahnya prestasi belajar matematika. Hal tersebut sesuai dengan pendapat (Slameto, 2010) bahwa siswa dengan tingkat kecemasan yang tinggi 
tidak berprestasi sebaik siswa dengan tingkat kecemasan yang rendah (Utari Dian Rizky, dkk 2019).

Dan para siswa berfikir belajar matematika adalah hal yang membosankan dan menakutkan dan itu sudah tertanam pada diri mereka sehingga saat materi berlangsung mereka tidak dapat memahaminya siswa yang memiliki kesulitan dalam memahami pelajaran matematika maka hasil belajarnya pun akan rendah (Tiara Ariska, 2020). Siswa sering kali menyelesaikan permasalahan dengan menggunakan rumus atau aturan yang umum dan kecemasan dalam mengerjakan soal.

"Siswa mengerjakan soal hanya terpaku kepada satu cara saja terkadang di rumah orang tua siswa lebih paham akan materi tetapi siswa tetap mengikuti cara guru yang di ajarkan disekolah"

Guru hendaknya memberikan pemahaman kepada peserta didik untuk menyelesaikan soal dengan pemahaman sendiri tanpa terpaku kepada satu cara saja. Belajar matematika tidak hanya sekedar menghapal rumus saja, namun melatih siswa agar berpikir kritis bagaimana cara mendapatkan jawaban dari permasalahan yang diberikan ( Atika Nur \& Amir Zubaidah MZ, 2016). Rata-rata siswa masih mengalami kesulitan dalam menerapkan rumus-rumus, kurangnya memahami teorema-teorema, bahkan yang paling banyak siswa masih mengalami kesulitan dalam memahami permasalahan dalam suatu soal matematika. Penyebabnya adalah cara belajar siswa yang cenderung menghafalkan materi dan rumus sehingga tidak ada konsep yang jelas. Siswa hanya menghafal rumus tanpa memahami maknanya, apabila menemui soal yang berbeda siswa tidak tahu menjabarkannya. (Siti Nur Aliah \& Martin Bernard, 2020).

"Siswa terkadang cemas dalam mengerjakan tugas yang telah diberikan guru"

Ketakutan yang sebenarnya dari pelajaran matematika adalah anak takut jika jawaban yang didapatkannya salah, karena jawaban yang salah berarti kegagalan sehingga anak dituntut untuk selalu bisa memberikan jawaban yang benar. Ketakutan atau rasa takut akan matematika dapat diartikan sebagai kecemasan matematika. Kecemasan dianggap sebagai satu faktor penghambat dalam belajar yang dapat mengganggu kinerja fungsi-fungsi kognitif seseorang, seperti dalam berkonsentrasi, mengingat, pembentukan konsep dan pemecahan masalah (Muhammad Rifqi Al Firari \& Widodo Winarso, 2020).

Kecemasan dalam matematika akan menyebabkan siswa cenderung merasa cemas, khawatir, dan cenderung takut jika soal-soal yang diujikan itu sulit atau kurang dipahami oleh dirinya, dan siswa cenderung pesimis sehingga akan berakibat pada rendahnya hasil 
belajar. Tidak sedikit pula siswa yang memiliki rasa cemas pada saat belajar matematika namun hasil belajar siswa tersebut baik hasilnya. Hal ini disebabkan siswa berusaha lebih keras dalam memahami hal yang dipelajarinya (Muhammad Rifqi Al Firari \& Widodo Winarso, 2020).

\section{Ketidakkemampuan siswa belajar secara mandiri}

"Siswa kadang hanya mau menyontek kepada teman sebangku saja tanpa ada usaha untuk mengerjakan soal yang telah diberikan oleh guru"

Menurut Markaban (dalam Siagian Muhammad Daut, 2016) "tingkat pemahaman matematika seorang siswa lebih dipengaruhi oleh pengalaman siswa itu sendiri." Hal ini berarti pemahaman seorang siswa dalam belajar diperoleh dari apa yang ia alami dalam pembelajaran tersebut. Selanjutnya, Bruner (dalam Siagian Muhammad Daut, 2016) menyatakan, pembelajaran matematika merupakan usaha untuk membantu siswa dalam mengkonstruksi pengetahuan melalui proses, karena mengetahui adalah suatu proses, bukan suatu produk. Siswa hendak berusah terlebih dahulu dalam mengerjakan soal dan mencoba lagi dan lagi agar siswa mempunyai pengalaman.

Menurut Zentall dan Smith (dalam Vaughn, dkk., 2013) siswa dengan gangguan perilaku, keterbelakangan mental, ketidakmampuan belajar, dan bermasalah dalam fokus/perhatian dalam belajar biasanya mendapatkan nilai lebih rendah dibandingkan anak-anak seusianya dalam pembelajaran matematika. Beberapa kesulitan siswa dalam matematika berhubungan dengan memahami masalah. Dalam kasus lain, siswa tidak memiliki keterampilan perhitungan untuk menyelesaikan masalah secara memadai. Biasanya, siswa dengan kebutuhan khusus memiliki kesulitan dengan masalah matematika dan prosedur penyelesaiannya (Yeni Ety Mukhlesi, 2015).

Berdasarkan problematika yang di hadapi pada aspek lingkungan dijelaskan bahwa:

\section{Suasana kelas yang kurang kondusif}

"Suasana kelas yang kurang kondusif yang dapat menganggu konsentrasi siswa dalam belajar"

Oleh karena itu, penting sekali bagi setiap guru memahami sebaik-baiknya tentang proses belajar siswa, agar ia dapat memberikan bimbingan dan menyediakan lingkungan belajar yang tepat dan serasi bagi siswa-siswa terutama di sekolah sehingga proses pembelajaran dapat berjalan dengan kondusif (Indra Sri Apnita, 2019). 


\section{KESIMPULAN}

\section{Simpulan}

Berdasarkan hasil penelitian yang dilakukan dapat di ambil kesimpulan bahwa terdapat beberapa problematika pada pembelajaran matematika yang guru hadapi selama proses pembelajaran yaitu antara lain: aspek guru kesulitan mengembangkan materi yang ada dalam buku karena teralu banyak materi yang akan diajarkan dan guru hanya menggunakan pendekatan pembelajaran konvensional. untuk aspek peserta didik yaitu kurangnya minat belajar siswa pada pelajaran matematika, pemahaman konsep yang kurang matang, semangat belajar yang kurang dan siswa tidak termotivasi saat belajat matematika, dikalangan siswa banyak yang memandang matematika adalah mata pelajaran yang sulit dan membosankan, siswa sering kali menyelesaikan permasalahan dengan menggunakan rumus atau aturan yang umum dan ketidakkemampuan siswa belajar secara mandiri. Dan yang terakhir adalah aspek lingkungan suasana kelas yang kurang kondusif.

Pentingnya pemahaman konsep matematika bagi siswa sekolah dasar ini menyebabkan guru harus lebih belajar giat agar menemukan solusi-solusi untuk mengatasi kesulitan yang dihadapi, solusi yang ditawarkan oleh peneliti kepada guru yaitu: 1) Guru harus memberikan motivasi belajar kepada siswa; 2) menggunakan metode, media dan strategi pembelajaran yang tepat; 3) menggunaan metode campuran pada saat proses pembelajaran, dan 4) ikut aktif dalam kelompok kerja guru (KKG) yang telah di tetapkan agar dapat menunjang kemampuan guru dalam mengajar.

\section{Saran}

Saran pada penelitian ini adalah Pentingnya pemahaman konsep matematika bagi siswa sekolah dasar ini menyebabkan guru harus berusaha menemukan solusi-solusi untuk mengatasi kesulitan yang dihadapi. Berikut merupakan solusi-solusi yang dapat guru terapkan dikelas untuk membantu guru dalam mengajarkan materi matematika dikelas.

Solusi yang digunakan oleh guru untuk mengatasi kesulitan-kesulitan dalam proses pembelajaran matematika dalam kelas sebagai berikut: Memberikan motivasi belajar kepada siswa berdasarkan minat belajar siswa yang kurang, sebagai guru harus seringsering memberikan motivasi tentang pentingnya belajar matematika bagi kehidupan seharihari. Guru juga harus membangkitkan motivasi belajar siswa dengan terus memberikan ulasan-ulasan materi dengan metode-metode dan strategi belajar yang menarik sehingga memunculkan rasa penasaran serta minat siswa untuk mengetahui sesuatu.

Menggunakan media belajar yang tepat pada proses pembelajaran matematika penggunaan media sangat membantu guru dalam memahamkan kepada siswa terutama 
tenang konsep materi matematika yang akan dipelajari. Penggunaan metode campuran penggunaan metode campuran akan sangat efektif bagi guru yang kesulitan membelajarkan tematik dikelas. Karena tematik merupakan system pembelajaran yang saling berkaitan antara materi yang satu dengan yang lainnya maka penggunaan metode ini membantu guru selama poses mengajar karena penggunaan metode campuran dapat menyesuaikan kebutuhan guru dan kebutuhan siswa. Sangat disarankan bagi guru yang masih kesulitan dalam menerapkan metode ceramah dikelas untuk mulai mencoba menerapkan metode campuran. Hal ini dapat membantu siswa lebih aktif dalam belajar dan guru tidak kesulitan dalam menyesuaikan metode pembelajaran apa yang dapat mencakup semua materi.

Ikut aktif dalam kelompok kerja guru (KKG) Kegiatan kelompok kerja guru merupakan wadah yang berfungsi sebagai penunjang kegiatan belajar mengajar dikelas yang membahas tentang kesulitan-kesulitan guru, strategi pembelajaran, membuat alat peraga membuat lembar kerja, lembar tugas, serta membahas masalah-masalah apa saja yang dialami setiap guru dikelas dan kemudian mencari solusi yang tepat untuk mengatasi masalah yang ada.

\section{REFERENSI}

Aliah, S. N. \& Bernard, M. (2020). Analisis Kesulitan Siswa dalam Menyelesaikan Soal Pemecahan Masalah Berbentuk Cerita pada Materi Segitiga dan Segiempat. Suska Journal of Mathematics Education, 6(2), 111-118.

Al Firari, M. R. \& Winarso, W. (2020). Kecemasan dan Kebiasaan Belajar Matematika terhadap Keterampilan Berpikir Kritis Siswa. Suska Journal of Mathematics Education, 6(1), 047-060.

Amir, Z. (2015), Mengungkap Seni Bermatematika dalam Pembelajaran. Suska Journal of Mathematics Education, 1(1), 60- 76.

Anwar, S. E. dkk. (2020). Level Berpikir Kreatif Siswa SMP dalam Menyelesaikan Masalah Matematika dengan Pendekatan Realistic Mathematics Education. Jurnal Maju, 7(2), $59-67$.

Atika, N. \& MZ, Z. A. (2016). Pengembangan LKS Berbasis Pendekatan RME untuk Menumbuhkembangkan Kemampuan Berpikir Kritis Matematika Siswa. Suska Journal of Mathematica Education, 2(2), 103-110. 
Ariska, T. (2020). Analisis Kesulitan Belajar Matematika Siswa Kelas V pada Materi KPK dan FPB Madrasah Ibtidaiyah Negeri 2 Kota Palembang. El-Ibtidaiy: Journal of Primary Education, 3(1), 36-42.

Elfina, H. (2020). Penerapan Pembelajaran Berbasis Masalah Berbantuan Software Autograph untuk Meningkatkan Kemampuan Komunikasi Matematik Siswa Kelas XI SMA Negeri 11 Medan. Jurnal Maju, 7(2), 221-227.

Fauzi, A. dkk. (2020). Kesulitan Guru pada Pembelajaran Matematika di Sekolah Dasar. Jurnal Ilmiah Mandala Education, 6(1), 142-148.

Fika, N. dkk. (2020). Penerapan Expert Riview sebagai Strategi Formative Evaluation dalam Mengembangkan Lks Matematika Berbasis Problem Posing, Jurnal Maju, $7(2), 156-164$.

Indra, S. A. (2019). Peningkatan Pemahaman Konsep Pembagian Pecahan dengan Pendekatan Realistic Mathematic Education di Kelas V Sdn 003 Pulau Kopung Kecamtan Sentajo Raya Kabupaten Kuantan Singingi. Jurnal Pendidikan dan Pengajaran, 3(2), 353-359.

Kamarullah, (2017). Pendidikan Matematika di Sekolah Kita. Jurnal Pendidikan dan Pembelajaran Matematika, 1(1), 21-32.

Muntaha, A. dkk. (2020). Analisis Kesulitan Siswa dalam Mengonstruksi Model Matematika pada Soal Cerita. Jurnal Maju, 7(2), 53-58.

MZ, Z. A. (2013). Perspektif Gender dalam Pembelajaran Matematika. Marwah: Jurnal Perempuan, Agama dan Jender, 12(1), 15-31.

Novitasari, D. (2016). Pengaruh Penggunaan Multimedia Interaktif terhadap Kemampuan Pemahaman Konsep Matematis Siswa. Jurnal Pendidikan Matematika dan Matematika, 2(2), 8-18.

Pasaribu, E. Z. dkk. (2020). Pengembangan Lembar Kerja Siswa Matematika Berbasis Model Discovery Learning terhadap Kemampuan Pemahaman Konsep Matematis Siswa Kelas XI di SMA Negeri 1 Rantau Selatan. Jurnal Maju, 7(2), 212-220.

Putri, B. A. \& Sofyan F. A. (2020). Analisis Kesulitan Proses Pembelajaran Berbasis Hots di Kelas VSDN 4 Muara Padang. El-Ibtidaiy: Journal of Primary Education, 2(2), $59-73$. 
Rostika, D. dan Herni, J. (2017). Peningkatan Kemampuan Pemecahan Masalah Siswa SD dalam Pembelajaran Matematika dengan Model Diskursus Multy Representation (DMR). Jurnal Pendidikan Dasar, 9(1), 35-46.

Selvianiresa, D. (2017). Kesulitan Siswa Sekolah Dasar pada Materi Nilai Tempat Mata Pelajaran Matematika di Kelas I SD. Jurnal Ilmiah Pendidikan Dasar, 2(1), 65-73.

Siagian, M. D. (2016). Kemampuan Koneksi Matematik dalam Pembelajaran Matematika. Journal of Mathematics Education and Science, 2(1), 58-67.

Utami, D. P. \& Andriani, M. (2019). Upaya Meningkatkan Motivasi Belajar Matematika Melalui Penerapan Model Pembelajaran Kooperetif Tipe Team Assisted Individualization. El-Ibtidaiy: Journal of Primary Education, 2(1), 9-17.

Utari, D. R. dkk, (2019). Analisis Kesulitan Belajar Matematika dalam Menyelesaikan Soal Cerita. Jurnal Ilmiah Sekolah Dasar, 3(4), 534-540.

Yeni, E. M. (2015). Kesulitan Belajar Matematika Di Sekolah Dasar. Jurnal JUPENDAS, $2(2), 1-10$. 